\title{
Student perceptions' of the educational environment in the midst of curriculum change
}

\author{
Diantha Soemantri ${ }^{1}$, Sue Roff $^{2}$, Sean McAleer ${ }^{2}$
}

\begin{abstract}
Abstrak
Kurikulum Fakultas Kedokteran Universitas Indonesia (FKUI) mengalami perubahan besar pada tahun 2005. Suatu evaluasi terhadap atmosfir pendidikan dalam kurikulum baru perlu dilaksanakan, sebagai bagian dari keseluruhan proses evaluasi kurikulum. Pada bulan Juni 2007, instrumen Dundee Ready Education Environment Measure (DREEM) diberikan kepada 210 mahasiswa tingkat dua yang mengikuti kurikulum baru dan 259 mahasiswa tingkat tiga yang menjalani kurikulum lama, untuk menilai persepsi mahasiswa terhadap atmosfir pendidikannya. Salah satu perbedaan yang signifikan antara persepsi kedua kelompok mahasiswa adalah terdapat lebih sedikit masalah menyontek di tingkat dua, namun penjadwalan kegiatan di tingkat tiga lebih baik. Profil persepsi mahasiswa dari kedua kelompok yang hampir sama mengindikasikan bahwa atmosfir pendidikan dalam kurikulum baru belum meningkat secara signifikan. Hal ini erat hubungannya dengan permasalahan dalam manajemen dan organisasi aspek detail kurikulum baru. Institusi pendidikan perlu menilai kembali persepsi mahasiswa setelah kurikulum baru sudah lebih terinternalisasi. (Med J Indones 2008; 17: 57-63)
\end{abstract}

\begin{abstract}
The Faculty of Medicine University of Indonesia underwent a major curriculum reform in 2005. There is a necessity to evaluate the new curriculum's educational environment, as a part of the curriculum evaluation. In June 2007, the DREEM (Dundee Ready Education Environment Measure) was administered to 210 second year students with an innovative curriculum and 259 third year students with the more traditional curriculum, to measure the students' perceptions of the educational environment. One of the most significant differences between the perceptions of the two groups is that there are less cheating problems in the second year, but the third year is better timetabled. The almost similar profiles indicate that the new curriculum's educational environment has not improved significantly. It is related with problems in managing and organizing the new curriculum's detail aspects. The institution needs to re-evaluate the perceptions of the educational environment when the curriculum is more internalised. (Med J Indones 2008; 17: 57-63)
\end{abstract}

Keywords: educational environment, DREEM, curriculum change, curriculum evaluation

An educational environment is the manifestation of a curriculum, as stated by Genn. ${ }^{1}$ Rothman \& Ayoade consider the learning environment as 'a manifestation of the effects on students of the various parts of the curriculum'. ${ }^{2}$ The components of the curriculum, or what Genn refers to as curriculum desiderata, are elements of the environment which represent the curriculum and thus, characterize the medical school. ${ }^{1}$

Genn \& Harden suggested that although the concept is rather intangible, the effects of an educational environment are substantial, real and influential. ${ }^{3}$ The climate makes a notable contribution to the prediction of student achievement, satisfaction and success. ${ }^{3,4}$ The medical

\footnotetext{
1 Department of Medical Education, Faculty of Medicine University of Indonesia, Jakarta, Indonesia

2 Centre for Medical Education, University of Dundee, Scotland
}

school learning environment is one of the determinants of the medical student's behaviour. ${ }^{1}$ However, it is the environment as perceived by the students which is related to the students' behaviour.

The Faculty of Medicine University of Indonesia (FMUI) has implemented the new curriculum, called the FMUI Competency Based Curriculum, since the academic year of 2005/2006. The FMUI Competency Based Curriculum is considered to be an innovative curriculum because it complies with the recommendations of curriculum innovation proposed by the General Medical Council of the United Kingdom. In academic year 2006/2007, two batches of students followed the new curriculum, whereas year 3-6 students followed the old one.

Since educational environment is a manifestation of a curriculum, then an assessment of the educational environment of an institution becomes an integral part 
of a curriculum evaluation. Rothman \& Ayoade measured the changes in the learning environment which are caused by the curriculum changes, as a part of the curriculum evaluation. ${ }^{2}$ The World Federation for Medical Education considers the learning environment as one of the targets for the medical education programmes evaluation. ${ }^{5}$

In order to obtain valid and meaningful information about the educational environment of FMUI, it is important that a suitable educational environment measurement instrument is utilised. According to its psychometric qualities, The DREEM is likely to be the most suitable instrument for measuring the students' perceptions of the educational environment in the undergraduate medical education setting. ${ }^{6}$ The objective of this research paper was to identify whether significant differences in students' perceptions of the educational environment exist between that of the innovative curriculum and that of the more traditional one using the DREEM instrument.

\section{METHODS}

The DREEM was translated into the Indonesian language (Bahasa Indonesia). After the cross-translation process, the translated version was piloted with ten second year students. After few ambiguous statements were clarified, the final version of the instrument was ready to be administered.

The anonymous instruments were administered to all second year students and third year students at the FMUI within the same academic year (2006/2007). The second and third year students followed the innovative curriculum and the more traditional one respectively. The instrument was distributed to the classes following a lecture or plenary session in order to obtain as many responses as possible. The distribution took place in June 2007 which was nearly the end of the academic year.

The instrument consists of 50 statements, with a 5-point Likert-type scale response format ranging from Strongly Agree to Strongly Disagree. The score for each item ranges from 4 (strongly agree) to 0 (strongly disagree), except for nine items which are negatively worded and thus, the scoring must be reversed. There are five subscales within the DREEM which are perceptions of learning (12 items), perceptions of teachers (11 items), academic self-perceptions (8 items), perceptions of atmosphere (12 items) and social self-perceptions
(7 items). The maximum score is 200 , which indicates an ideal educational environment as perceived by students.

The data from the two sample groups were analysed and compared using the non-parametric test (MannWhitney $U$ test) to identify whether significant differences in students' perceptions of the educational environment exist between that of the innovative curriculum and that of the more traditional one. A difference with the $\mathrm{p}$ value of less than 0.05 was considered to be statistically significant. The reliability of the full instrument and its subscales were computed using the SPSS 14.0 programme and expressed as the Alpha coefficient ranging from 0 to 1 .

\section{RESULTS}

\section{Response rate and demographic data}

One hundred and sixty-eight out of 210 (80\%) questionnaires were completed and returned by the second year students. The response rate for third year class was $188 / 259(72.6 \%)$. The age of the second year respondents ranged from 17 to 21 year-olds with the majority of them at the age of $19(45.8 \%)$. Most of the third year respondents were 20 year-old $(49.2 \%)$, with the range from 19 to 23 year-olds.

There were 64 (out of 83; 77.1\%) and 103 (out of 127; $81.1 \%$ ) second year males and females respondents respectively. One respondent did not provide the information on gender. Of the 158 third year respondents, 75 (out of $109 ; 68.8 \%$ ) were males and 111 (out of $140 ; 79.3 \%$ ) were females and two respondents did not provide the information.

\section{Reliability of the instrument}

The Indonesian version of the DREEM was proven to have adequate reliability with the reliability (Alpha) coefficient of 0.88 . The reliability coefficients for the instrument's subscales ranged from 0.57 to 0.69 .

\section{Year differences}

The mean scores of the full instrument and its subscales are presented in Table 1. The $\mathrm{p}$ value for each comparison is presented in Table 2. The total scores of the two groups do not differ significantly.

Second year students perceived the atmosphere as better compared to their counterpart in the third year. 
Whereas the third year students have better academic self-perceptions compared to those of the second year. In the analysis of individual items, there are only ten items of which the scores differ significantly (Table 2). The most significant differences exist in the area of teachers' skills and behaviour, school's timetable, emphasis on learning approach, cheating problems and continuity of curriculum content/structure.
Five individual items with the highest and lowest scores in each year are presented in Table 3. The identification of these items allows one to assess the strengths and weaknesses of each curriculum. The results indicate that the strong points, as well as the areas of concern, of both curricula are almost similar.

Table 1. Mean scores of the subscales and overall instrument for the second and third year

\begin{tabular}{lrrr}
\hline Subscale & $\begin{array}{r}\text { Year 2 } \\
(\mathrm{N}=168)\end{array}$ & $\begin{array}{r}\text { Year 3 } \\
(\mathrm{N}=188)\end{array}$ & p value \\
\hline $\begin{array}{l}\text { Students' perceptions of learning } \\
\text { (maximum score: 48) }\end{array}$ & 31.08 & 30.44 & 0.223 \\
$\begin{array}{l}\text { Students' perceptions of teachers } \\
\text { (maximum score: 44) }\end{array}$ & 28.33 & 27.78 & 0.159 \\
$\begin{array}{l}\text { Students' academic self-perceptions } \\
\text { (maximum score: 32) }\end{array}$ & 20.34 & 20.99 & $0.045^{*}$ \\
$\begin{array}{l}\text { Students' perceptions of atmosphere } \\
\text { (maximum score: 48) }\end{array}$ & 29.25 & 28.13 & $0.023^{*}$ \\
$\begin{array}{l}\text { Students' social self-perceptions } \\
\text { (maximum score: 28) }\end{array}$ & 16.21 & 15.91 & 0.242 \\
$\begin{array}{l}\text { Overall instrument } \\
\text { (maximum score: 200) }\end{array}$ & 125.13 & 123.45 & 0.281 \\
\hline
\end{tabular}

* Statistically significant different score between year 2 and 3 ( $\mathrm{p}$ value $<.05$ )

Table 2. Items with statistically significant different scores between year 2 and 3

\begin{tabular}{|c|c|c|c|c|}
\hline Item & Statement & $\begin{array}{r}\text { Year 2 } \\
(\mathrm{N}=168) \\
\end{array}$ & $\begin{array}{r}\text { Year 3 } \\
(\mathrm{N}=188) \\
\end{array}$ & $\mathrm{p}$ value \\
\hline 6 & The teachers are patient with patients & 2.45 & 2.16 & 0.000 \\
\hline 11 & $\begin{array}{l}\text { The atmosphere is relaxed during the ward/clinical } \\
\text { teaching }\end{array}$ & 2.20 & 2.04 & 0.001 \\
\hline 12 & This school is well timetabled & 2.02 & 2.54 & 0.000 \\
\hline 17 & Cheating is a problem in this school ${ }^{\dagger}$ & 2.54 & 1.61 & 0.000 \\
\hline 18 & $\begin{array}{l}\text { The teachers have good communication skills with } \\
\text { patients }\end{array}$ & 2.55 & 2.32 & 0.000 \\
\hline 25 & The teaching over-emphasizes factual teaching ${ }^{\dagger}$ & 1.80 & 1.54 & 0.002 \\
\hline 26 & $\begin{array}{l}\text { Last year's work has been a good preparation for } \\
\text { this year's work }\end{array}$ & 2.40 & 2.9 & 0.000 \\
\hline 34 & $\begin{array}{l}\text { The atmosphere is relaxed during the } \\
\text { seminars/tutorials }\end{array}$ & 2.69 & 2.52 & 0.009 \\
\hline 40 & The teachers are well prepared for their classes & 2.69 & 2.88 & 0.024 \\
\hline 47 & $\begin{array}{l}\text { Long-term learning is emphasized over short-term } \\
\text { learning }\end{array}$ & 2.57 & 2.2 & 0.000 \\
\hline
\end{tabular}

$\dagger$ The statements with negatively worded items and reversed scoring 
Table 3. Five individual items with the highest and lowest scores in year 2 and 3

\begin{tabular}{llr}
\hline Item No & Statement with highest scores & Score \\
\hline & Year 2 & 3.26 \\
15 & I have good friends in this school & 3.14 \\
2 & The teachers are knowledgeable & 3.14 \\
10 & I am confident about passing this year & 3.08 \\
45 & Much of what I have to learn seems relevant to a career in healthcare & 2.96 \\
19 & My social life is good & 3.32 \\
& Year 3 & 3.24 \\
15 & I have good friends in this school & 3.12 \\
10 & I am confident about passing this year & 3.07 \\
2 & The teachers are knowledgeable & 2.9 \\
45 & Much of what I have to learn seems relevant to a career in healthcare & \\
26 & Last year's work has been a good preparation for this year's work & 1.84 \\
\hline Item No & Statement with lowest scores & 1.8 \\
\hline & Year 2 & 1.74 \\
4 & I am too tired to enjoy this course & 1.57 \\
25 & The teaching over-emphasizes factual learning & \\
14 & I am rarely bored on this course & 1.47 \\
3 & There is a good support system for students who get stressed & 1.7 \\
27 & I am able to memorize all I need & 1.64 \\
& Year 3 & 1.61 \\
3 & There is a good support system for students who get stressed & 1.54 \\
14 & I am rarely bored on this course & 1.39 \\
\hline 17 & Cheating is a problem in this school & \\
25 & The teaching over-emphasizes factual learning & \\
27 & I am able to memorize all I need &
\end{tabular}

${ }^{\ddagger}$ The statements with negatively worded items and reversed scoring

\section{DISCUSSION}

The response rates obtained in this study are lower compared to those of similar studies. ${ }^{7,8}$ However, they are higher than that obtained by Dunne et $\mathrm{al}^{9}$ and comparable to those in Mayya \& $\operatorname{Roff}^{10}$ and Zaini ${ }^{11}$. The difficulty of having all students gather in one time and place is the main barrier of achieving a higher response rate. As previously described, small group activities play a significant role in both years. The time constraint in conducting this study made it difficult to wait for the most appropriate time.

The full instrument has a high reliability coefficient (0.88) based on its administration to 356 students. The reliability coefficients of the subscale are acceptable (0.62 to 0.69), except for those of the academic selfperceptions and social self-perceptions subscale which are considerably low (0.57). Previous studies produced high reliability coefficients of the full instrument which ranged from 0.88 to $0.92 .{ }^{10-13}$ This finding further suggests that the DREEM is a reliable instrument throughout its administration in different settings and countries.

The overall mean scores for year 2 and 3 are 125.13 and 123.45 respectively. The scores indicate that both groups perceived their educational environment as reasonably positive, although improvements in certain areas must be taken into consideration. The overall mean score of the innovative curriculum group is lower than that of a UK medical school (139) as reported by Al-Hazimi et $\mathrm{al}^{7}$. However, it is higher than the score of 109.9 reported by Bassaw et al from a medical school with an innovative curriculum in Trinidad Tobago. ${ }^{14}$

The score of the third year students, who experienced the more traditional curriculum, is higher than the scores obtained in other medical schools with traditional curriculum. ${ }^{7,15}$ However, the curriculum in the third year at the FMUI is not entirely traditional. There are some elements of innovative curriculum which are applied in this curriculum such as student- 
centred teaching method (small group discussion) and horizontal integration.

The fairly similar overall mean scores from both groups indicate that students from both curricula perceived the educational environment as considerably positive despite the differences of the two curricula. If comparison between the scores of the two curricula is to be made, then it should be done with caution because the two groups originate from different years of study. Therefore, any differences occur in the perceptions of the educational environment may not be caused by differences in the curriculum, but rather other factors such as age difference, maturity and experience. A decline in the satisfaction to the educational environment may be caused by the higher expectations as students mature.

The subscale scores demonstrated that there are slight improvements in the scores of the new curriculum group, except for the academic self-perceptions subscale in which students from older curriculum have significantly higher score compared to that of the new curriculum. Students from the older curriculum may have better academic self-perceptions because they are older, more mature and more experienced and therefore they feel more prepared and more confident as medical students. Jiffry et al demonstrated an increasing trend of the students' academic selfperceptions scores from pre-clinical to clinical years. ${ }^{15}$ These might suggest that students' academic selfperceptions are also affected by the experiences and maturity of the students, rather than the curriculum type alone.

The students from the new curriculum perceived the atmosphere as significantly better compared to the students from the older curriculum. The activities of the new curriculum students are dominated by small group activities in which most often there is a closer interaction between the students and teacher. The students are more encouraged and motivated to participate and learn and also more comfortable in expressing themselves.

The findings in this study suggest that although it is expected that students from the new curriculum perceive the educational environment as better, there are certain areas which are perceived better by the old curriculum students. The introduction and implementation of a new curriculum produce a great deal of confusion and sometimes disorganization both for students and teachers. Roff et al also noted that curriculum change is a stressful process for students and faculty members. ${ }^{16}$
As the new curriculum in FMUI has just entered its second year of implementation, many changes and improvements are still introduced. Although the curriculum has been implemented, it is still in the transition phase in which the detail and practical aspects of the curriculum are often refined and reorganised.

The analysis of the individual items indicates some areas in which third year students have significantly higher scores compared to the second year ones. Those items are "the school is well timetabled", "the teachers are well prepared for their classes" and "last year's work has been a good preparation for this year's work". These areas of concern are highly related with the problems in management and organization of the new curriculum. A highly integrated course with collaboration among many pre-clinical and clinical departments causes many difficulties in managing the course's timetable. The teachers might not be well prepared because confusion and disagreements about the depth and coverage of the content often arise.

The areas of which students from the new curriculum perceived as significantly better compared to the students from the older curriculum demonstrated the strengths of an innovative curriculum. The factual teaching is less emphasised and more emphasis is put on the long-term learning rather than short-term learning. The atmospheres during most of the activities are more relaxed. In the activities related to clinical practice, the teachers were patient and demonstrated good communication skills with the patient. However, this particular area must be interpreted carefully since the students may not have enough exposure to clinical practice to be able to provide judgement.

Although the new curriculum put less emphasis on factual learning compared to that of the older one as perceived by the students, the over-emphasis on factual learning is still a major weakness of both curricula as indicated by the individual item scores (Table 3). The students also indicated that they are having difficulties in memorizing the necessary information. This problem might be highly related with the over-emphasis on factual learning and information overload in the curriculum.

The lack of student support system is also a significant weakness of the educational environment of both curricula. The new curriculum has incorporated academic advisors programme, in which every student is assigned to an academic advisor during his/her study. An academic advisor is responsible for monitoring 
the academic progress of the students and also dealing with non-academic problems that might affect the students. However, the findings of this study indicate that the programme has not been conducted properly and thus, special attention should be given to the programme as the first gateway for students with problems.

The students from the new curriculum indicated that they were too tired to enjoy the course. The modulebased system of the curriculum with summative examinations in every six weeks might contribute to this problem. This might bring too much stress for the students, as they are expected to be on top of their performance starting from the first day of the module. A prominent weakness of the educational environment in the third year, which does not occur in the second year, is the cheating problem. The situation that cheating has become a regular part of students' life especially in the third year should alert the faculty. The over-emphasis on factual and short-term learning, information overload and poor assessment system might have caused this problem.

The new curriculum aims to organise its content accordingly for students to be able to see the relevance of what they learn since the start of their study, since relevance increases retention and understanding. The third year curriculum has minimal clinical sciences involvement. However, the curriculum content runs under the pathological sciences stream, and thus students might be able to see the relevance of the knowledge even without the early introduction to clinical practice, as in the new curriculum. The different level of study between the two groups in this study may bias the results and makes it difficult to determine whether the educational environment of the new curriculum has improved significantly.

Both groups perceived their teachers as knowledgeable. Being knowledgeable does not necessarily mean that they are good teachers. It is essential to look for other qualities of the teachers, such as the type and skills of teaching, to determine whether the teachers in the faculty have maintained high standards. The third year students also demonstrated that last year's work has been a good preparation for this year's work. This does not happen for the second year students. As previously stated, the third year students may feel more confident about their academic progress because they are more experienced and mature. The existing problems in managing and organising a new curriculum may hinder the strength of the new curriculum that should provide continuity of its content and structure.

A re-administration of the DREEM in the future, by which time the new curriculum will be internalised within the students and faculty, may show a higher satisfaction and significant improvements of the educational environment of the new curriculum. A notable weakness of this study is the fact that the comparison is made between the scores of students from different year. Therefore, the data should be interpreted carefully since any differences occurred may be caused by the differences in the year of study, rather than the type of curriculum. A more valid result can be obtained if the data from a cohort of students who follows the more traditional curriculum at a particular year of study is compared with the data from another cohort of students who follows the new curriculum at the same year of study.

\section{CONCLUSION}

The almost similar profile of the strengths and weaknesses of the environment of both curricula also require the faculty's attention that the educational environment of the new curriculum has not yet improved significantly. In spite of the limitation of this study in which the sample groups do not originate from the same level of study and thus requires a more careful interpretation of the results, the instrument is able to capture the significant problems regarding the implementation of a new curriculum which mostly deal with the management and reorganisation of the detail content and practical aspects of the curriculum.

\section{Acknowledgement}

The author would like to thank the students of the FMUI who were willing to participate in this study and assist in the data gathering process. My gratitude also goes to my former teachers who have now become my mentors.

\section{REFERENCES}

1. Genn JM AMEE Medical Education Guide no.23 (part 1): curriculum, environment, climate, quality and change in medical education - unifying perspective. Med Teach. 2001; 23:337-44.

2. Rothman AI, Ayoade F. The development of a learning environment: a questionnaire for use in curriculum evaluation. J of Med Educ. 1970;45:754-9. 
3. Genn JM, Harden RM. What is medical education here really like? Suggestions for action research studies of climates of medical education environments. Med Teach. 1986;8:111-24.

4. Genn JM. AMEE Medical Education Guide no.23 (part 2 ): curriculum, environment, climate, quality and change in medical education - unifying perspective. Med Teach. 2001;23:445-54.

5. World Federation for Medical Education. International standards in medical education: assessment and accreditation of medical schools' - educational programmes: a WFME position paper. Med Educ. 1998;32:549-58.

6. Soemantri D. Measuring the educational environment in health professions studies: a systematic review to identify the a valid and reliable instrument for use at the Faculty of Medicine University of Indonesia [dissertation]. Dundee: University of Dundee, Scotland; 2007.

7. Al-Hazimi A, Zaini R, Al-Hyani A, Hassan N, Gunaid A, Ponnamperuma G, Karunathilake I, Roff S, McAleer S, Davis $\mathrm{MH}$. Educational environment in traditional and innovative medical schools: a study in four undergraduate medical schools. Educ for Health. 2004;17:192-203.

8. Till H. Identifying the perceived weaknesses of a new curriculum by means of the Dundee Ready Education Environment Measure (DREEM) inventory. Med Teach. 2004;26:39-45.

9. Dunne FS, McAleer S, Roff S. Assessment of the undergraduate medical education environment in a large UK medical school. Health Educ J. 2006;65:149-58.
10. Mayya SS, Roff S. Students' perceptions of educational environment: a comparison of academic achievers and under-achievers at Kasturba Medical College, India. Educ for Health. 2004;17:280-91.

11. Zaini R. Use of Dundee Ready Education Environment (DREEM) for curriculum needs analysis in the Faculty of Medicine and Medical Sciences at Umm Al-Qura University, Saudi Arabia [dissertation]. Dundee: University of Dundee, Scotland;2003.

12. Al-Zidgali L. Students' approaches to studying at the Institute of Health Sciences, Sultanate of Oman [dissertation]. Dundee: University of Dundee, Scotland; 1999.

13. Al-Qahtani MF. Approaches to study and learning environment in medical schools with special reference to the Gulf Countries [dissertation]. Dundee: University of Dundee, Scotland;1999.

14. Bassaw B, Roff S, McAleer S, Roopnarinesingh S, de Lisle J, Teelucksingh S, Gopaul S. Students' perspectives on the educational environment, Faculty of Medical Sciences, Trinidad. Med Teach. 2003;25:522-6.

15. Jiffry MTM, McAleer S, Fernando S, Marasinghe R. Using the DREEM questionnaire to gather baseline information on an evolving medical school in Sri Lanka. Med Teach. 2005;27:348-52.

16. Roff S, McAleer S, Harden RM, Al-Qahtani M, Ahmed A, Deza H, Groenen G, Pimparyon P. Development and validation of the Dundee Ready Education Environment Measure (DREEM). Med Teach. 1997;19:295-9. 